\title{
THE PHENOMENON OF THE MIGRATION AND THE QUALITY AND THE SUBSISTENCE LEVEL OF THE POPULATION OF RURAL AREAS IN MALOPOLSKA
}

\author{
Magdalena Kowalska ${ }^{1}$
}

Received 22 June 2010; Accepted 17 September 2010

\begin{abstract}
The present work is about the influence of migration on the quality and the subsistence level of the inhabitants from the six communities of Zakliczyn, Iwanowice, Czchów, Wieliczka, Zielonki, Drwinia located in the Malopolska voivodship. The quality of life of the examined households is not satisfying and the subsistence level of families, defined on basic cost patterns, is low. The principal costs are the so-called indispensable expenses. Such expenses include those which every household must bear; such as food and housing. There is pressure on the development of the social and technology infrastructure to lower unemployment so as to encourage inhabitants, especially the young of the community, to limit their outflow abroad.
\end{abstract}

Key words: migrations, the quality of life, the subsistence level, rural areas

Abstract: Zjawisko migracji a jakość i poziom życia ludności obszarów wiejskich w Małopolsce. W opracowaniu zostały zaprezentowane wyniki badań przeprowadzonych w sześciu gminach z terenu województwa małopolskiego (Zakliczyn, Iwanowice, Czchów, Wieliczka, Zielonki, Drwinia), a dotyczących wpływu migracji na jakość i poziom życia ich mieszkańców. Jak wynika z przedstawionej charakterystyki jakość życia badanych gospodarstw domowych nie jest zadowalająca., a poziom życia rodzin, określany na podstawie struktury wydatków należy określić jako niski. Dominująca pozycje zajmuja tzw. wydatki niezbędne, czyli takie, które każde gospodarstwo domowe musi ponieść (należą do nich żywność i opłaty mieszkaniowe). Konieczne jest położenie nacisku na rozwój infrastruktury społecznej i technicznej oraz zmniejszenie bezrobocia tak aby zachęcić mieszkańców, szczególnie młodych do pozostania na terenie gminy i w ten sposób ograniczyć ich odpływ za granicę.

Key words: migracje, jakość życia, poziom życia, ludność wiejska, obszary wiejskie

\section{Introduction}

The problem presented is the phenomenon of migration. The origins of the word migration are from Latin ("migratio") and mean displacement, as well as social mobility (Kopaliński, 2001).

\footnotetext{
${ }^{1}$ Dr. Magdalena Kowalska, Hugo Kollątaj Agricultural University Kraków, Department of Sociology and Development of the Rural Areas, Al. Mickiewicza 21, 31-120 Kraków, Poland, e-mail: mkowalska@ar.krakow.pl
} 
Migration is strictly connected with the conscious displacement of persons. It is the "relatively permanent removal of individuals and groups within the framework of a determined space" (Bokszański, 1999).

One can also define migration according to the criterion of the activity, as "the economically conditioned population transfer" (Kaczmarczyk, 2005). It binds the migration with the move and the character of executed activities (eg. gainful employment).

While migration, as defined by Giddens (2005) as "the overspill from the country for the purpose of settlement elsewhere". Giddens (2005) also states that, migration "movements contribute to the cultural and ethnic enrichment of many societies, shaping their population, economic, and social dynamics".

The problem of social mobility has been a topic of Polish public opinion for some time. The outflow abroad is not a new phenomenon and has been registered for several years on a wide scale. But the close connection with what is happening on the local and global scale along with social - economic factors, makes the current exploratory problem a subject of study for many scientific disciplines. The estimation, the scale and the structure of contemporary external migrations is based on department data, general censuses, data from the Research of the Activity of the Economic Sector of the Population, data accumulated by accepting countries and on results of previous migration research.

However, these sources together with introduced liberalization of border traffic regulations and contemporary changes in the character of migration do not paint a complete picture of this phenomenon.

Doubtless the phenomenon of migration is not without influence on the local community. Interesting conclusions are supplied by Górniak (2007) who analysed several titles from the local press from different regions of Poland. She writes: "The local press, first of all tries to depict the negative sequences of regular migration for society and individuals; showing to various degrees, the decline in local communities. The local press uses rhetoric and ideology based on the national character such as national values, motherland, tradition, the good of the nation, and family customs."

But is it really possible to change the direction of the style of the local press? Such a style dictates that people who leave "univocally are treated as disloyal and giving up obvious duties" and are "in contradiction with the idea of patriotism" (Górniak 2007).

The next section will deal with quality of life and the subsistence level problems of the inhabitants of rural areas from the region of Malopolska.

In Europe, for the first time with the creation EEC in August, 1949, the defining of aims for future integration associated with quality of life on a larger scale began to be dealt with. However, in Union statistics this notion appeared only in the 1970's. At this time attention returned to the social aspects of integration. From that moment, the quality of life of the population, the aspirations for improvement and the lessening of disproportional social- policy levels, formed the organization in this region (Kubicka 2001).

According to Luszniewicz (1959) subsistence level is: "the degree of satisfaction of material and cultural needs of households, concerning goods, payable services and shared, collective expenditures".

Below are the presented findings from six communities from the region of the Malopolska voivodship, (Zakliczyn, Iwanowice, Czchów, Wieliczka, Zielonki, Drwinia). The findings concern the influence of migration on the quality and the subsistence level of the inhabitants from this area.

The level and the quality of life are dependent on the particular circumstances and the developmental potential of a community. Among the different conditions considered are: the financial circumstances, housing, the quality of the natural outdoor environment, the quality of the transportation infrastructure, the social and cultural settings, etc. The quality rating of life demands the recognition of needs and aspirations of the population which inhabits the community. 
For the special aspect of subjective quality ratings of life, it is important to acknowledge the feeling of satisfaction of being with somebody in ones own social milieu. Social - demographic factors are indispensable in determining and differentiating the feeling of satisfaction or the lack of satisfaction. Additionally, the presented findings targeted the degree of differentiation in living conditions of the inhabitants of the six Malopolska communities and an estimation of their standard of living.

\section{Paid work abroad and the quality and the subsistence level of inhabitants of Malopolska - observed findings. The migration among members of examined households}

The mean age of respondents was 43 years. Most respondents were 40 to 50 years old (34\%). The least numerous group was the group of young people up to 20 years old.

Most respondents (44\%) had skilled training or postsecondary-schooling, (15\%) did not finish their basic education. Respondents with a higher education (4\%) were in the minority.

In the group was a prevalence of farm workers $(54 \%)$ working as wage laborers. The least were the self-employed $(4 \%)$, and $19 \%$ were in agricultural. A large percentage of farms $(23 \%)$ were run from non salaried sources such as a pension, or different kinds of benefit funds.

The scale of the paid emigration in the examined communities is as follows: from among 560 examined households, in about $68 \%$ an immediate family member had left, and $20 \%$ would leave if only such an opportunity occurred.

Only $27 \%$ of the households stated that their family members were not interested in earning a living outside the borders of the country.

It is not possible to say here about any groupings by area of people who were not interested in leaving the country because such situations appeared in many different isolated incidents in many places of the appointed research areas. The vast majority of respondents came from families in this group (having nobody abroad and not planning to leave). This group was mainly young, well educated women with fulfilling work in which they found much satisfaction. Examples of women in this group were; teachers, pharmacists, bookkeepers, the owner of a chain of stores, a clerk. They represented families for which the main source of income was the fixed wage, or their own economic activity. In one case the source of income for a family was made from the farm.

Reasons indicated by the group of respondents for why they do not intend to work outside of Poland concerned first of all, an interesting and quite well-paid job, the proximity of family, chances for professional advancement in Poland, "patriotic" motives or the fact that they had already had certain experiences connected with paid work in foreign countries and did not intend to repeat them.

A somewhat different social - demographic picture is presented about professional persons who decided to leave home to go to a foreign country. Most often these skilled workers were young (in the age bracket of from $22-40$ years), single men $(60 \%)$. These young men mainly had a basic skilled-training (44\%) education or a standard education (35\%). They came from families where the source of income was: the paid fixed wage or social services (pensions, benefits). Very seldom was the farm (approx. 15\%) the source of income for skilled workers who emigrated.

Western European countries dominated the list of countries where people usually emigrated. England and Ireland were first on the list (almost $70 \%$ all countries indicated), Germany (approx. $7 \%$ ) and to Scandinavia (almost 13\%). Other countries people emigrated to were: Italy, Austria, Holland, France, Greece and marginally overseas (U.S.A., Canada, Australia).

Persons who decided to leave the country in order to work, found jobs mainly in construction and the hotel trade, but also as "domestic help", nursemaids, cleaners, drivers, restaurant workers or as automobile mechanics etc. The person from their family who was polled believed that their family member would stay abroad not shorter than a year. Seldom did a person state that they do not want to return to Poland or that they planned to stay abroad forever. 
However, persons polled who stay abroad state almost unanimously that they are satisfied with their own living conditions and the work. They indicated that their satisfaction stems from a lack of financial worries which gave a sense of stabilization and security. The negatives of this type of emigration are the separation from the family and possible "changes in character".

From among the reasons given for making a decision to leave Poland, most often are the financial reasons. The low wages in Poland, unavailable work and better working conditions abroad, as well as a wish to replace a missing object, were the reasons given for leaving the country in approx. $81 \%$ all answers. Some respondents stated that: curiosity about another country, the wish to improve their job qualifications, the wish to learn about new cultures or the possibility of meeting interesting acquaintances were also reasons for leaving Poland.

Persons polled stated that from the moment somebody from their family left for abroad, the financial situation of the family decidedly improved. Respondents spoken to indicated that they spend the money which they received from across the border, first of all on investments for the house or the flat, for the establishment of their own firm, for expenses associated with running a household and for the education of family members. The most seldom chosen eg. tourist trips or for one's own "whims".

Finally it is necessary to mention the group which declared that if only they had a favorable opportunity they would leave Poland. Here, clearly women (approx. 68\%) dominated, and the average age was 32 years. Seventy per cent of this group noted that they knew a foreign language enough to communicate with foreigners. This group was dominated by persons with a higher education. The average types of jobs these people (approx. 65\%) held were: economist, teacher, historian, librarian, electronic engineer, cook, and bricklayer.

On the question about why they would like to leave Poland and why they would choose a specific country (aside from financial reasons), they answered that they had been to the country and were already familiar with the particular country $(31 \%$ answers), because this country lies not far from Poland (approx. 20\%), and also that they would be able to easily find a job in their field (almost $43 \%$ ).

\section{The quality and the subsistence level of investigated households:}

A point to be taken into consideration about country-households is that there is a joining of incomes from the farm and a domestic and mutual manner of income dispersal. Obtained earnings are intended both for the purchase of production goods, and to increase savings, as well as, household needs (Żelazna 1993).

Respondents were asked to name and order the monthly expenses of their families on a scale from 1 to 10. The results are shown below (Graph 1).

From among all of the family monthly expenses the greatest percent was for: flats and food (approx. 40\%). Expenses on higher-order goods, that is on culture etc. were at the end of the hierarchy. Among "other expenses" respondents mentioned eg. charges connected with the maintenance of the car and farms (taxes), education costs, the repayment of loans, and incidentals such as: presents for grandchildren etc.

The meaning of subsistence level in the investigated households was influenced by the possibility of satisfying needs with objects of permanent use. The tight financial situation of respondents often caused limitations in this range. Among investigated farms most needed objects of permanent use included: the vacuum cleaner, the cellular phone, the freezer and the car. The camera and the dishwasher belonged to the category of objects seldom needed for subsistence level satisfaction.

Representatives of the investigated households gave subjective estimations of the own financial situation. Most of those investigated (63\%) evaluated their financial situation as good, every fifth person stated that financially he/she fared well, and $3 \%$ of respondents said their financial situation was very bad. The results showed that the best evaluation of the financial situation of their own family were the persons receiving pensions. Students and the unemployed stated their financial situations to be the worst. 


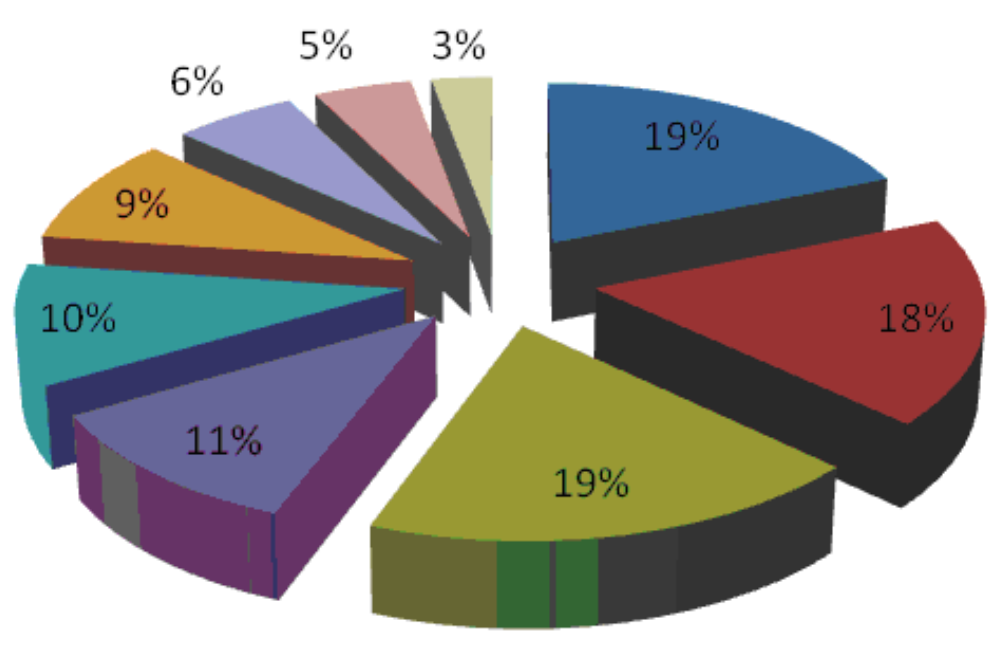

housing costs

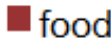

wealth

clothing

expenses for children

personal hygiene

culture oriented activities

alcohol, cigarettes

other charges

Fig 1. Monthly expenses in households

Half of the respondents said that compared to 5 years ago their financial situation was worse. Only $10 \%$ acknowledged that their financial situation had improved.

Additional questions concerning the financial situation of the family of the respondent concerned bank accounts, credit cards, company or investment funds, and possible savings. Answers showed that $88 \%$ of respondents or spouses of respondents have a bank account, $15 \%$ have a credit card, and $10 \%$ invest their funds.

Savings are essential for a feeling of stabilization and vital safety. A large part of the investigated farms (approx. 28\%) are in debt. In $20 \%$ there are no savings, and $1 \%$ admits that it never had savings.

Those which evaluated their own situation as good had very good savings. Those respondents who in their own opinion are on a fixed income, not only do not have savings but most are in debt.

The possibility of the satisfaction of housing needs by the investigated families is treated as one of basic determinants of the subsistence level. The estimation of housing conditions was carried out on the basis of data analyses of the following:

- number of persons per household,

- the kind of the flat, the year it was built and the general material it is made of,

- the degree of technical - sanitary installations,

- proximity of public transport,

- the state of nearby natural environmental surroundings,

- subjective estimations of how long respondents had been living in a given place and possible number of move.

The average number of rooms amounted to 6,9. Kitchens and bathrooms were not included as rooms. The most numerous group was made up of flats with 6-7 rooms. It is important to note that flats were roomy and big.

Research results show that the fastest housing development in this region took place in the years 1945 - 1974. In this period $51 \%$ of buildings were built. The average age of a respondents house was 35 years.

An important element of the housing conditions was the technical - sanitary installations. Almost all investigated farms were equipped with running water, $74 \%$ it possessed a bathroom with a bath or shower, $77 \%$ had central heating (the remaining families heat with coal-burning stoves), and only $14 \%$ had an internet connection. 
The vast majority of the farming households investigated, defined their state of life as good, and only $2 \%$ strongly stated their way of life was difficult. In $76 \%$ of country households, members of the family commute to schools away from home. Three-quarters of the respondents stated that transportation connections to their places were good or very good.

Respondents from the country were asked for an estimation of the state of the natural environment surrounding their homes. The answer most often given was that the state of the natural environment surrounding their homes was good, and only $4 \%$ defined it as bad. The question about whether environmental pollution makes the quality of life in the country worse caused very divergent answers. Every fourth person ascertained that environmental pollution had an influence on the quality of life and decidedly makes the quality of life worse. According to $25 \%$ of those investigated environmental pollution had only a minor influence on the quality of life. For $37 \%$ of people from the country investigated, environmental pollution does not have the influence on the quality of life, and $20 \%$ + did not have an opinion.

The next part of the research concerned the opinion of respondents on the subject of what is lacking, which makes the quality of life in the country worse. In first place was the answer that the job shortage (as $87 \%$ of the cases answered) makes the quality of life in the country worse. Other answers included: the sewer system, the bad quality of roads, the lack of sidewalks for pedestrians, the lack of places to go for entertainment, the lack of an internet connection, and also the lack of schools, nursery schools, nurseries and shops.

Representatives of investigated farms, in the overwhelming majority stated that they are satisfied living where they do, however approx. 19\% of them said they were not satisfied. Reasons for satisfaction were among other things: that they liked the village and village life, they appreciated the peace and quiet, they liked the region and clean air, that they were brought up and have families in the area. Tradition was also given as an answer associated with satisfaction.

Major causes of dissatisfaction mentioned by those investigated were the following: the lack of a future and perspectives for a better the life in the country, difficulties of village life, the lack of the profitability of agricultural production and the lack of schools to which one can send children.

According to Suprewicz (2005) free time "is the time left over that a person has at his or her disposal after all required activities such as the school, work, and activities connected with daily life needs are finished".

The notion of free time appeared in social research alongside the subject of industrial society. In traditional society free time was not considered important because free time and the working period were not considered as separate.

A change in standards now allows that free time fulfils the family, the peer group and life at home. The free time of people coming from the country-side is dependent mainly on financial means and the quantity of available time.

The most popular form of free time among respondents from the country, was watching television programs. The second most popular form of free time was visiting friends and family. In third place $(22 \%)$ was vacations which include walks, cycling tours, fishing etc.

More than half of the respondents acknowledged that they did not often have the possibility of planning their free time for activities they could enjoy. Almost as many persons voiced an opinion that where they lived, there were no places where one can pleasantly spend planned free time. This contributes to the view given by respondents living in the country, that the place where they live is not attractive, is not interesting, and has nothing to offer. Those respondents who acknowledged that they knew of nearby places of interest noted community centers, recreation rooms, bars, cafés and sport fields.

Rest is usually essential for the maintenance of both the physical and mental condition. Unfortunately inhabitants of the investigated communities rarely take holiday trips. It turned out that nearly $70 \%$ of the representatives from the investigated households never go for a vacation, and one-fifth does so less than every 2-3 years. 
Differentiated conditions in which we live and relations prevailing in the near and not so near environment influenced to a degree, the satisfaction or the dissatisfaction in the lives of the respondents.

Most of the respondents said the reasons for their satisfaction were: their own families (55\%), health $(16 \%)$, and work $(12 \%)$. However, $7 \%$ of them said they had no reasons for satisfaction or could not indicate what makes them happy.

From the list of unalleviated needs, particular deficiencies and important difficulties, respondents most often chose the lack of opportunities to make additional money (52\%), the lack of money which they could use to set aside (49\%) and health problems (39\%). Only $6 \%$ complained that they were not necessary to somebody $(6 \%)$. Nearly a tenth of respondents acknowledged that nothing important was lacking in their life.

\section{Summary}

Reasons of external migrations remain vital to the social needs of many people. External migrations of inhabitants from the six Malopolska communities have a huge influence on all spheres of the psycho-social level and on the quality of life.

The most dangerous though least visible changes caused by emigrations happen on the family level because basic social functions are disturbed. The more-than-once long-lasting separations make for alienation of family members and for breakdowns in the family.

Decidedly, the most visible sphere of influence of paid external migrations in the investigated households was the economic factor. The quality of life improved considerably for those who had worked abroad. Financial improvements were an essential component of their household budgets.

There was a lack of agreement among respondents when evaluating the material situation of the local community in which they live: one- twentieth said that they came from a poor community, and twice as many gave the opposite opinions, evaluating the local population as wealthy.

The sensitive studies of external migrations among those investigated from the country, showed that persons with the greatest mobility were those with comparatively high social potential. These persons were relatively well educated, open to the world, interesting, and inclined to take risks. Also, extended family connections played a role.

The subsistence level of the investigated families, defined on the basis of cost patterns ought to be defined as low. The dominant position such cost patterns occupy, are the so-called indispensable expenses. These are the expenses which every household must bear. Food and housing (approx. $40 \%$ of all expenses) fall into this category.

For the full picture of the financial situation of investigated families it is important to note that almost one-third of the investigated farms is in debt, and a fifth has no savings and never had savings.

Housing conditions of respondents can be defined as relatively good and include technical sanitary installations and durable goods.

Despite all inconveniences and shortages within the social - cultural infrastructure range (the lack of places to spend free time in the given community etc.) and despite the technical inconveniences and shortages, the vast majority of respondents were satisfied living in the country. They indicated that the advantages of the country are the clean fresh air, the wide outdoors, and the peace and quiet. They said these factors make it worthwhile living in the country.

The realistic, represented depiction of the quality and the subsistence level of the investigated households is not satisfying. It is necessary to develop the social and technical infrastructure. Unemployment must be addressed and resolved so as to encourage inhabitants, especially the young to stay in the community and thus, limit their outflow abroad. 


\section{References}

[1] Bokszański, Z., Ed. (1999). Encyklopedia Socjologii. Warszawa: Oficyna Wydawnicza.

[2] Giddens A. (2005). Socjologia. Warszawa: PWN.

[3] Górniak K. (2007). W kręgu lokalności. (In) Wieruszewska M. (Ed.), Tu i tam. Migracje z polskich wsi za granicę. Warszawa: IRWiR.

[4] Kaczmarczyk P. (2005). Migracje zarobkowe Polaków w dobie przemian. Warszawa: Wyd. UW.

[5] Kopaliński W. (2001). Słownik wyrazów obcych i zwrotów obcojęzycznych. Warszawa: De Agostini Polska.

[6] Kubicka J. (2001). Proces integracji europejskiej a poziom życia ludności. Katowice

[7] Luszniewicz A. (1959). O metodach badania budżetów rodzinnych w Polsce w latach 1920 1957. Warszawa: PWG.

[8] Słaby T. (1996). Poziom życia, jakość życia. Wiadomości Statystyczne. Nr 6/1996.

[9] Suprewicz J.C. (2005). Socjologia turystyki. Lublin: Wydawnictwo Akademickie WSSP. 